Role of nutrition in mental health among students from University of Assiut

\author{
*Nareman S. Eshak and **Samuel T. Boshra \\ *Lecturer of Nutrition and Food Science, Home Economics Dept., Facul. of specific Ed. \\ Assiut Univ. \\ *AAssist. Prof., Psychology Dept., Facul. of Ed. Assiut Univ.
}

\begin{abstract}
Certain food items might be more frequently eaten under personal stress or depressive state. We examined nutritional habits associated with depression, self-esteem, anxiety and aggression symptoms and the relationship by gender in a sample of students from the University of Assiut. The study discussed the role of nutrition in mental health: depression, self-esteem anxiety and aggression in sample of Students from the University of Assiut. 225 students (males and females) from Assiut University were chosen. They were subjected to socioeconomic history and diet history taking. The tests used were the measure of depression, self-esteem, anxiety, and aggression, using the correlation coefficient. Results revealed that depression was significantly reduced among the participants at $(P<0.01)$ when eating protein, starchy, sugary foods, legumes, fruits and vegetables, but was significantly increased when eating fatty food items and drinking beverages. In contrast, self-esteem was significantly increased when eating protein, starchy, sugar food items and legumes, but was significantly decreased when eating fruits and vegetables and drinking beverages. Eating protein, starchy, sugary food items, legumes, fruits and vegetables reduced anxiety, but drinking beverages increased anxiety and aggression. Also, aggression was significantly increased by eating protein rich food items, but eating legumes, fruits and vegetables decreased aggression among the participants.
\end{abstract}

\title{
Introduction
}

Dietary habits are a major aspect of people's lifestyles that influence health, morbidity, and mortality for a range of conditions. Hence, patterns of food consumption and their relation to mental health have received some attention in research (Benton, 2002). For example, some observational and experimental studies explored the effects of carbohydrate intake on mood. Other studies have assessed the association between stress and food selection, reporting partly conflicting results. Carbohydrate consumption has been hypothesized to relieve depressive moods, and this has been considered as part of the causal link for developing obesity. However, the association has also been seen in the opposite direction, with stress and depressive symptoms resulting in poorer food choices (Liu et al., 2007). Indeed, studies on the effects of stress on food choice show that people experiencing periods of stress reported overeating food items they would normally avoid, and that they ate these foods to feel better (Zellner et al., 2006).

Self-esteem is crucial part of every person, and is essential to living a happy and productive life. Self-esteem can be described as people's images of themselves. According to Banos and Guillen (2000), self-esteem is the general attitude a person has about their own self-value. The most well adjusted people have moderately high self-esteem. 
They tend to feel good about themselves and at the same time are able to admit they have flaws. However, not everyone is able to feel this way. People with low self-esteem tend to struggle through life (Janda, 2001). Finding the key to self-esteem may not only help people feel better about themselves, but help those to live happier and more well adjusted lives.

Anxiety is defined as uneasy anticipation of the future, which is filled with worry and concern (Janda, 2001). It can also be described as a feeling of apprehension about different events in one's life. People tend to have anxiety towards things they have little control over. Some people avoid certain situations in anticipation of anxiety. This restricts their lives and makes them dependent on others (Janda, 2001). Aggression is defined as every act that leads to harming others, and may be hurt physically or psychologically (Ellie et al., 2010). Also, Van et al., (2011) mentioned that the concept of aggression means: "any act practiced by a group or individual against other individuals through the taunting words or an act of violence actually reflects the moral or physical force".

The researches conclude that the aggression appears in two aspects: first; physical abuse resulting in injury, disability or death using the hands or sharp tools to achieve the goal, second; verbal abuse, to use words and phrases graffiti caused frustration at the other end so as to lead to psychological problems.

The present work aimed to study the role of nutrition in mental health: depression, self-esteem anxiety and aggression in a sample of Students from the University of Assiut.

\section{Students and Method}

Participants 225 students were included in this study. Of those, 82 were males $((\mathrm{M}$ age $=20.2$ years, range $=19$ to 21.1 years, $S D=0.615$ ), and 143 were females $(M$ age $=19.9$ years, range $=19.1$ to 20.9 years, $S D=0.601) . A l l$ participants were university students, attending Assuit University. All students came from fourth class at Faculty of Education and Faculty of Specific Education.

\section{Mental Health Measurements}

Social and psychological data were collected, besides eating pattern and types of food. State of depression was tested using the developed Self-Rating Depression Scale. This test was intended for ease of administration while measuring the severity of depression. It is a 20 item test with a four point scale, with 1 (none or a little of the time), 2 (some of the time), 3 (good part of the time), and 4 (most or all of the time). Half of the items are worded positively and half negatively; therefore the reverse scored items are two, five, 11, 12, 14, 16, 17, 18, and 20. The possible range of scores is $20-80$, with higher scores indicating more depression. Zung reported significant correlations between even and odd questions. In general, this test successfully discriminates between depressed and non-depressed individuals, but the test is limited in determining the severity of depression (Robinson et al., 1991). There was a relationship between the self-rating depression scale and other measures of depression. Such as the Hamilton Rating Scale for Depression and the Beck Depression Inventory, the correlations were high to moderate (Robinson et al., 1991).

Self-Esteem was tested using the self-esteem scale developed by Rosenberg (Robinson et al., 1991). The 10 questions self-scale was scored using a four point scale, ranging from strongly agree (1) to strongly disagree (4). The scores on this test range from 10-40, with lower scores indicating higher self-esteem. Questions three, five, eight, nine, and ten are reversed scored. The test-retest correlation reported for this test is a .85. The Rosenberg questionnaire found a correlation of .72 with the Lerner Self-Esteem Scale (Robinson et al., 1991). 


\section{Egypt. J. of Nutrition and Health Vol. 7 No. 1 (2012)}

Anxiety was tested using the the State Trait Anxiety Inventory, or the STAI (see Appendix C). The test was developed by Spielberger et al., 1983. The test contains 20 items on a four-point rating scale, 1 being "Almost never" and 4 indicating "Almost always". The possible range of scores is $20-80$, with higher scores indicating higher anxiety. An example question is "I feel pleasant". The trait anxiety reliability ranged from. 73 to.86. The state of anxiety was relatively low, ranging from .16 to .62 with a medium reliability coefficient of .33 (Spielberger et al., 1983). Aggression was tested using the developed Aggressive Scale. This test was intended for ease of administration while measuring the severity of aggression. It is a 15 item test with a three point scale, with 1 (Often), 2 (sometimes), and 3 (Rarely).

\section{Dietary Intake}

Dietary intake of commonly consumed food items was collected from all participants using a researcher created Food Frequency Questionnaire (FFQ) (22 indicator variables). Participants were asked to report, on a scale ranging from "never" to "1 or more per day or week or month", how often they eat each variety of food items. Food groups that were questioned include, bread, rice, pasta, potatoes, grits, sugar, honey, jam, halva, oil, margarine, butter, meat, poultry, fish, eggs, cheese, milk, legumes, fruits, vegetables, and beverages (like tea, coffee, juice,.......etc) .

In order to analyze this data, results were recalculated such that an answer of 'never' was translated into zero, ' once per month', was translated into 1.0, '1' per week was translated into 4, ' 2 ' per week was translated into 8,3 ' per week was translated into 12,'4' per week was translated into $16,{ }^{\prime} 5$ ' per week was translated into $20, ' 6$ ' per week was translated into 24, ' 1 per day' was translated into 30 , '2 per day' was translated into 60 , ' 3 per day' was translated into 90 , and 'NA' was translated into 0 . These recordings were chosen to represent the number of instances each month that a respondent ate each food. The instrument was created to include food groups that are important when studying dietary habits, in line with other research studies (Von Bothmer\& Fridlund, 2005).

\section{Design}

This study had a between-subject quasi-experimental design. The independent variable was dietary intakes, and the dependent variables were depression, self-esteem, anxiety and aggression. Other explanatory variables measured age, and gender. Results were analyzed using Version 16 Statistical Package for Social Science (SPSS), using the Pearson correlation coefficient, and use "t- TEST"

\section{Results}

Table (1) shows means and std. deviations of the mental variables for both males and females. The mean of depression was $(44.61 \pm 9.64 \& 44.27 \pm 9.83)$ for males and females respectively. But the mean of self esteem was $(20.90 \pm 5.69 \& 21.01 \pm 5.21)$ for males and females respectively. While, the mean of anxiety was $(46.71 \pm 9.29 \&$ $47.43 \pm 9.23)$ for males and females respectively. The mean of aggression was $(24.41 \pm 6.84 \& 26.14 \pm 6.87)$ for males and females respectively. 
Table (1):

Means and Std. deviations of the mental variables for both males and females

\begin{tabular}{l|c|c|c|c}
\hline \multicolumn{1}{c|}{ Variable } & \multicolumn{2}{|c|}{$\begin{array}{c}c \\
\mathrm{n}=82\end{array}$} & \multicolumn{2}{c}{$\mathrm{N}=143$} \\
\cline { 2 - 5 } & Mean & std.deviation & Mean & Std.deviation \\
\hline 1. Depression & 44.61 & 9.64 & 44.27 & 9.83 \\
\hline 2. Self -esteem & 20.90 & 5.69 & 21.01 & 5.21 \\
\hline 3. Anxiety & 46.71 & 9.29 & 47.43 & 9.23 \\
\hline 4. Aggression & 24.41 & 6.84 & 26.14 & 6.87 \\
\hline
\end{tabular}

Table (2) represents the correlations between food consumption and perceived stress and depressive symptoms for males for mental health indicators. The mean depression was significantly decreased in male students eating protein foods frequently at ( $P \square 0.01)$. Also, the mean depression was significantly decreased in males students eating (starchy and sugary) foods, legumes, fruits and vegetables frequently at $(P<0.01)$. While the mean depression was significantly increased in males students eating fatty foods and drinking beverages frequently at $(P<0.01)$.

Table (2):

Correlation Coefficients between food consumption and depressive symptoms, self-esteem, anxiety and aggression for males for mental health indicators

\begin{tabular}{|c|c|c|c|c|}
\hline Variable & Depression & Self-Esteem & Anxiety & Aggression \\
\hline 1.Protein foods & -0.734 & 0.850 & -0.559 & 0.674 \\
\hline P.value & $\begin{array}{c}\star \star \star \\
P<0.01\end{array}$ & $\begin{array}{c}\star \star \star \\
P<0.01\end{array}$ & $\begin{array}{c}\star \star \star \\
P<0.01\end{array}$ & $\begin{array}{c}\star \star \star \\
P<0.01\end{array}$ \\
\hline 2. Starchy foods & -0.752 & 0.422 & -0.469 & 0.018 \\
\hline P.value & $\begin{array}{c}\star \star \star \\
P<0.01\end{array}$ & $\begin{array}{c}\star \star \star \\
P<0.01\end{array}$ & $\begin{array}{c}\star \star \star \\
P<0.01\end{array}$ & n.s \\
\hline 3. Sugary foods & -0.700 & 0.42 & -0.510 & 0.021 \\
\hline P.value & $\begin{array}{c}\star \star \star \\
P<0.01\end{array}$ & $\begin{array}{c}\star \star \star \\
P<0.01\end{array}$ & $\begin{array}{c}\star \star \star \\
P<0.01\end{array}$ & n.s \\
\hline 4. Fatty foods & 0.601 & 0.096 & 0.024 & 0.126 \\
\hline P.value & $\begin{array}{c}\star \star \star \\
P<0.01\end{array}$ & n.s & n.s & n.s \\
\hline 5. Legumes & -0.778 & 0.489 & -0.550 & -0.446 \\
\hline P.value & $\begin{array}{c}\star \star \star \\
P<0.01\end{array}$ & $\begin{array}{c}\star \star \star \\
P<0.01\end{array}$ & $\begin{array}{c}\star \star \star \\
P<0.01\end{array}$ & $\begin{array}{c}\star \star \star \\
P<0.01\end{array}$ \\
\hline 6. Fruits/Vegetables & -0.536 & 0.481 & -0.409 & -0.466 \\
\hline P.value & $\begin{array}{c}\star \star \star \\
P<0.01\end{array}$ & $\begin{array}{c}\star \star \star \\
P<0.01\end{array}$ & $\begin{array}{c}\star \star \star \\
P<0.01\end{array}$ & $\begin{array}{c}\star \star \star \\
P<0.01\end{array}$ \\
\hline 7. Beverages & 0.562 & -0.346 & 0.418 & 0.583 \\
\hline P.value & $\begin{array}{c}\star \star \star \\
P<0.01\end{array}$ & $\begin{array}{c}{ }^{\star} \\
P<0.05\end{array}$ & $\begin{array}{c}\star \star \star \\
P<0.01\end{array}$ & $\begin{array}{c}\star \star \star \\
P<0.01\end{array}$ \\
\hline
\end{tabular}




\section{Egypt. J. of Nutrition and Health Vol. 7 No. 1 (2012)}

The mean self-esteem was significantly increased in male students eating (protein, starchy and sugary) foods, legumes, fruits and vegetables frequently at $(P<0.01)$. But the mean self esteem was significantly decreased in male students who drink beverages frequently at $(P<0.05)$. While the mean self esteem was not significant in male students eating a lot of fatty foods.

The males students eating (protein, starchy and sugary) foods, legumes, fruits and vegetables frequently had significant reduction in anxiety at $(P<0.01)$. While, the males students eating fatty foods had no significant change in anxiety. On drinking beverages students had significant increase in anxiety at $(P<0.01)$. The males students eating protein foods and drinking beverages had significant increased in aggression at $(P<0.01)$. But eating legumes, fruits and vegetables had significant reduction in aggression at $(P<0.01)$. While the males students eating (starchy, sugary and fatty) foods had no significant change in aggression.

Table (3):

Correlation Coefficients between food consumption and depressive symptoms, self-esteem, anxiety and aggression for females for mental health indicators:

\begin{tabular}{|c|c|c|c|c|}
\hline Variable & Depression & Self-Esteem & Anxiety & Aggression \\
\hline 1. Protein foods & -0.689 & 0.787 & -0.561 & 0.628 \\
\hline P.value & $\begin{array}{c}\star \star \star \\
P<0.01\end{array}$ & $\begin{array}{c}\star \star \star \\
P<0.01\end{array}$ & $\begin{array}{c}\star \star \star \\
P<0.01\end{array}$ & $\begin{array}{c}\star \star \star \\
P<0.01\end{array}$ \\
\hline 2. Starchy foods & -0.692 & 0.452 & -0.495 & 0.024 \\
\hline P.value & $\begin{array}{c}\star \star \star \\
P<0.01\end{array}$ & $\begin{array}{c}\star \star \star \\
P<0.01\end{array}$ & $\begin{array}{c}\star \star \star \\
P<0.01\end{array}$ & n.s \\
\hline 3. Sugary foods & -0.570 & 0.346 & -0.302 & 0.029 \\
\hline P.value & $\begin{array}{c}\star \star \star \\
P<0.01\end{array}$ & $\begin{array}{c}\star \star \star \\
P<0.01\end{array}$ & $\begin{array}{c}\star * \\
P<0.05\end{array}$ & n.s \\
\hline 4. Fatty foods & 0.587 & 0.181 & 0.062 & 0.175 \\
\hline P.value & $\begin{array}{c}\star \star \star \\
P<0.01\end{array}$ & n.s & n.s & n.s \\
\hline 5. Legumes & -0.754 & 0.412 & -0.532 & -0.440 \\
\hline P.value & $\begin{array}{c}\star \star \star \\
P<0.01\end{array}$ & $\begin{array}{c}\star \star \star \\
P<0.01\end{array}$ & $\begin{array}{c}\star \star \star \\
P<0.01\end{array}$ & $\begin{array}{c}\star \star \star \\
P<0.01\end{array}$ \\
\hline 6. Fruits/Vegetables & -0.538 & 0.512 & -0.406 & -0.448 \\
\hline P.value & $\begin{array}{c}\star \star \star \\
P<0.01\end{array}$ & $\begin{array}{c}\star \star \star \\
P<0.01\end{array}$ & $\begin{array}{c}\star \star \star \\
P<0.01\end{array}$ & $\begin{array}{c}\star \star \star \\
P<0.01\end{array}$ \\
\hline 7. Beverages & 0.543 & -0.332 & 0.451 & 0.300 \\
\hline P.value & $\begin{array}{c}\star \star \star \\
P<0.01\end{array}$ & $\begin{array}{c}{ }^{\star} \\
P<0.05\end{array}$ & $\begin{array}{c}\star \star \star \\
P<0.01\end{array}$ & $\begin{array}{c}* \\
P<0.05\end{array}$ \\
\hline
\end{tabular}


Table (3) illustrates the associations between food consumption and perceived stress and depressive symptoms for females for mental health indicators. The mean depression was significantly decreased in females students eating (protein, starchy, sugary) foods, legumes, fruits and vegetables frequently at $(P<0.01)$. But, the mean depression was significantly increased on eating fatty foods and drinking beverages frequently at $(P<0.01)$.

The mean self-esteem was significantly increased in female students eating (protein, starchy and sugary) foods, legumes, fruits and vegetables frequently at $(P<0.01)$. But the mean self-esteem was significantly decreased on drinking beverages frequently at $(P<0.05)$. Self-esteem did not change while eating a lot of fatty foods.

The females students eating (protein, starchy and sugary) foods, legumes, fruits and vegetables frequently had significant reduction in anxiety at $(P<0.01 \& P<0.05)$. In contrast, drinking beverages had significant increase in anxiety at $(P<0.01)$. While the female students eating fatty foods had no significant change in anxiety.

The female students eating protein foods and drinking beverages had significant increase in aggression at ( $P$ v0.01\& $P<0.05$ ). But the females' students eating legumes, fruits and vegetables had significant reduction in aggression at $(P<0.01)$. While the females students eating (starchy, sugary and fatty) foods had no significant change in aggression

Table (4):

t- values and degrees of freedom between males and females in the mental variables:

\begin{tabular}{c|c|c|c}
\hline Variables & $\mathrm{t}(2$ tailed $)$ & $\mathrm{df}$ & $\mathrm{p}$ \\
\hline Depression & .254 & 223 & .799 \\
\hline Anxiety & -.561 & 223 & .575 \\
\hline Aggression & -.149 & 223 & .881 \\
\hline Self - Esteem & -1.816 & 223 & .071 \\
\hline
\end{tabular}


Egypt. J. of Nutrition and Health Vol. 7 No. 1 (2012)

Table (5):

t- values and degrees of freedom between males and females in the dietary intakes:

\begin{tabular}{c|c|c|c}
\hline Variables & $\mathrm{t}(2$ tailed $)$ & $\mathrm{df}$ & $\mathrm{P}$. \\
\hline Protein foods & -.518 & 223 & .605 \\
\hline Starchy foods & -.643 & 223 & .521 \\
\hline Fruits/Vegetables & -1.022 & 223 & .308 \\
\hline Sugars & -.541 & 223 & .592 \\
\hline Fatty foods & -.348 & 223 & .673 \\
\hline Legumes & -.412 & 223 & .651 \\
\hline Beverages & -.293 & 223 & \\
\hline
\end{tabular}

Table (4) and (5) represent t- values and degrees of freedom and their significance between males and females in the mental variables and dietary intakes. The tables show no significant difference between sexes.

\section{Discussion}

The present study shows that the state of depression was significantly decreased in male and female students on eating protein rich food items frequently. This result is in agreement with Rob, et al, (2009) who reported that some research has suggested that high protein diets can actually reduce depression. Amino acids found in protein can help to replace a neurotransmitter deficiency that could affect mood. One such study published in the "American Journal of Clinical Nutrition" found that a certain bovine protein helped to reduce depression and improve coping skills. Also, this result is in agreement with Rafael, et al., (2009) who stated that in first-year students in Germany ( $=696)$, Poland ( $N$ $=489$ ) and Bulgaria $(\mathrm{N}=654)$ depressive symptoms were associated with less frequent consumption of meat.

Also, the mean depression was significantly decreased in male and female students eating starchy food items frequently. This result coincides with that of Cathy, (2007) who reported that oatmeal (kind of flour) may help if you find yourself feeling irritable and cranky. It is rich in soluble fibers, which helps to smooth out blood sugar levels by slowing the absorption of sugar into the blood.

However our result disagrees with Simon (2011) who suggested that symptoms can occur after just a small amount of eaten gluten, usually within about an hour of consumption, and may last up to a week. They include depression, stomach upsets, nasal blockages, chest problems, joint aches, abdominal and intestinal pains, and the reoccurrence of pain from old injuries (including back pain). Also, Simon (2011) reported that solanine found in potato starch can cause serious illness at concentrations of $>280 \mathrm{mg} \mathrm{kg-1} \mathrm{f.w.} \mathrm{Symptoms} \mathrm{generally} \mathrm{occur} \mathrm{after} \mathrm{8-12} \mathrm{hours} \mathrm{after}$ ingestion and can include gastrointestinal disturbances and neurological disorders. Mild symptoms can include headaches, dizziness, abdominal pain, nausea, vomiting and diarrhea. Other symptoms can include: depression, anxiety, fever, restlessness, drowsiness and mental confusion, trembling and hallucination, sleep disorders, loss of libido, 
clumsiness, coma, delirium, and a variety of pains in ribs and pelvis, coldness, anxiety, lack of sense of warmth and empathy for other humans, and visual effects.

The state of depression was significantly decreased in male and female students eating sugary food items frequently. This result disagrees with (Nancy, 2010) who reported that depression thrives on cakes, sugary pies, toffees, sweet drinks and chocolate bars. Also, the researchers at the University of California at San Diego have found in 931 adults who were not taking an antidepressant and did not have heart disease or diabetes that those who were most depressed also consumed the most chocolate and chocolate consumption seemed to correlate with the level of depression, with those who were not depressed eating 5.4 servings per month, while those with possible depression ate 8.4 and those with probable major depression ate 11.8 servings. Future studies are required to elucidate the foundation of the association," Said the authors, "and to determine whether chocolate has a role in depression, as cause or cure.

In males and females a positive correlation was found between the depression and eating fatty food items. This finding coincides with (Meredith, 2011) who stated in 12,059 college graduates (average age 37.5 years) the risk of developing depression increased as trans-fat consumption rose. Those in the highest quintile of trans-fat intake deriving at least $0.6 \%$ of their daily calories from trans fats - had a $42 \%$ increased risk of depression, compared with those in the lowest consumption group, who barely ate any trans fats at all. The study also found that people who ate a lot of monounsaturated and polyunsaturated fats, like those found in olive oil, had a lower risk of depression. Also, this result is in agreement with (Pouwer et al., 2005) who showed that a high intake of $\omega$-r PUFA protects against the development of depression. There is also some evidence that a low intake of $\omega-3$ is associated with an increased risk of Type 2 diabetes, but the results are less conclusive. Results from randomized controlled trials in non-diabetic subjects with major depression show that eicosapentaenoic acid is an effective adjunct treatment of depression in diabetes, while docosahexanoic acid is not. Moreover, consumption of $\omega-3$ PUFA reduces the risk of cardiovascular disease and may therefore indirectly decrease depression in Type 2 diabetes, via the reduction of cardiovascular complications. Thus, supplementation with $\omega$-3 PUFA, in particular eicosapentaenoic acid, may be a safe and helpful tool to reduce the incidence of depression and to treat depression in Type 2 diabetes. Further studies are now justified to test these hypotheses in patients with Type 2 diabetes.

There is a significant negative correlation between depression and eating legumes in our study. This result is in agreement with (American Heart Association, 2010) which mentioned that legumes such as lentils and split peas are packed with nutrients that might help to prevent and treat depression. Legumes are rich in folate, one of the B vitamins that is widely known for its ability to help prevent neural defects. Recently, research has shown that those diagnosed with depression also have low levels of folate. Alternatively, those who follow the Mediterranean diet, which contains ample amounts of legumes, are 30 percent less likely to experience depression. Legumes are considered one of the best foods for depression because they are believed to contribute to the proper functioning of certain brain chemicals that regulate mood, due to their impressive amounts of folate, one of the B vitamins. In addition, legumes' overall nutrient content might help reduce carbohydrate cravings that are frequently experienced by those with depression.

In males and females a negative correlation was found between the depression and eating fruits and vegetables. This coincides with Rafael et al., (2009) but in females only because who reported that for male students, none of the food consumption groups were associated with perceived stress or depressive symptoms. In females, perceived stress was associated with more frequent consumption of sweets/fast foods and less frequent consumption of fruits/vegetables. Additionally, depressive symptoms were associated with less frequent consumption of fruits/vegetables and meat. In the present study, the positive correlation between depression and drinking beverages may be due to frequently drinking tea and coffee which is in agreement with Cathy, (2007) who reported that although caffeine has been shown to lead to a more positive mood and improved performance, too much caffeine can make you dependent and make you nervous, irritable, and hypersensitive or induce headaches. 
In males and females a positive correlation was found between the self-esteem and eating starchy and sugary foods, but there is no significant relationship in both males and females between self-esteem and eating fatty foods, beside the fact that these foods lead to overweight and obesity. This is an interesting finding because it is different from previous findings (Martin et al., 1991) who revealed in adolescent females with abnormal eating that those with more unhappiness with their weight and higher scores on the eating attitudes test were more likely to have lower self-esteem and higher anxiety and to participate more in health-risk behaviors, including cigarette smoking, alcohol use, drug use, and sexual activity. Also, Richard, (2000) stated that in 1520 children, 9 to 10 years of age obese Hispanic and white females demonstrate significantly lower levels of self-esteem by early adolescence. In addition, obese children with decreasing levels of self-esteem demonstrate significantly higher rates of sadness, loneliness, and nervousness and are more likely to engage in high-risk behaviors such as smoking or consuming alcohol. Marci et al., (2001) reported in 76 overweight (body mass index $=36.76 .5 \mathrm{SD}$ ) outpatients (53 women and 23 men; aged 43.59 .5 years) entering a weight loss program that night eaters had higher depression $(p=0.04)$, lower self-esteem $(p=0.003)$, and less hunger $(p=$ $0.005)$, and a trend for more fullness $(p=0.06)$ before the daytime test meal than the others. This may be due to night eating syndrome (NES) is a syndrome with distinct psychopathology and increased food intake later in the day, both of which may contribute to poorer weight loss outcome. NES criteria need to be better quantified and NES deserves consideration as a diagnostic eating disorder.

The present study indicates that in males and females a negative correlation was found between anxiety and eating protein rich food items. This result agrees with Santucci et al., (1994) who mentioned in two animal models of anxiety (elevated plus-maze and light-dark transition tests) were used. Rats were malnourished by feeding their dams a $6 \%$ protein diet during the lactation period (0-21 days of age) while well-nourished controls received a $16 \%$ protein diet. From 21 to 70 days of age all rats received a balanced lab chow diet. The results showed that both diazepam and environmental stimulation reduced anxiety in the elevated plus-maze; stimulation changed the anxiolytic response to diazepam and the two diet conditions altered differentially the response to both pharmacological and stimulation procedures. In contrast Jerry, (2009) assessed that protein contains amino acids that affect neurotransmitters, powerful chemicals in the brain that influence mental performance and emotional states. While amino acids help body's growth, development and physical health, they also influence feelings and motivation. Mood changes and anxiety can develop when certain amino acids break down from proteins during digestion. Other amino acids can help relieve anxiety, depending on the foods eaten. People often benefit from a mental and physical lift after eating protein foods for breakfast and lunch. However, protein foods may have a negative effect on people suffering from anxiety. Some protein foods also contain carbohydrates that may help with relaxation.

In males and females a negative correlation was found between anxiety and eating starchy and sugary food items, but there is no significant relationship in both males and females between anxiety and eating fatty food items. These food items lead to overweight and obesity. This coincides with Gariepy et al., (2010) who reported that Subgroup analyses revealed a positive association in men and women. Overall, a moderate level of evidence exists for a positive association between obesity and anxiety disorders. Questions remain regarding the role of obesity severity and subtypes of anxiety disorders. The causal relationship from obesity to anxiety disorders could not be inferred from current data; future etiologic studies are recommended. A negative correlation was found between the anxiety and eating legumes. This finding is in agrees with (Jerry, 2009) who stated that Legumes contain high amounts of protein and carbohydrates that may help with relaxation.

Concerning the aggression, there is a significant positive correlation in both males and females between the aggression and eating protein rich food items. This result agrees with Armando, (1997) who mentioned that the effects of proteins can undoubtedly be seen in aggression, violence, hatred and moral insensitivity. All these proteins taken from the animal world means an absolute bloodbath, and it is not only unnecessary and morally repugnant, but also 
responsible for physical diseases brought on by toxaemia, even including cancer and psychological disorders brought on by the influence towards aggression. Also, this result coincides with Lew, (2010) who reported that in dogs with dominant aggression, the addition of tryptophan to high-protein diets or change to a low-protein diet may reduce aggression. For dogs with territorial aggression, tryptophan supplementation of a low-protein diet may be helpful in reducing aggression. There is no significant relationship in both males and females between the aggression and eating fatty foods. This finding disagrees with Beatrice et al., (2012) who stated that dietary trans fatty acids (dTFA) being primarily synthetic compounds that have been introduced recently; little is known about their behavioral effects. dTFA inhibit production of omega-3 fatty acids, which experimentally have been shown to reduce aggression. Potential behavioral effects of dTFA merit investigation. Greater dTFA were strongly significantly associated with greater aggression, with dTFA more consistently predictive than other assessed aggression predictors. Also, Hamazaki et al., (1996) reported that in 41 students who ingest either docosahexaenoic acid (DHA)-rich oil capsules containing 1.5-1.8 grams DHA/day (17 females and 5 males) or control oil capsules containing $97 \%$ soybean oil plus $3 \%$ fish oil ( 12 females and 7 males) for 3 mo in a double-blind fashion that DHA intake prevented extraggression from increasing at times of mental stress.

In males and females a negative correlation was found between the aggression and eating fruits and vegetables. This is in agreement with Lew, (2010) who suggested that more vegetables added to the dog's diet will curb aggression. There is no significant relationship in both males and females between the aggression and eating starchy\& sugary food. This result is in agreement with Diana\& Susan, (1995) who stated that the relationship between diet and behavior involving offender populations have not yielded evidence that a change in diet would result in significant reduction in aggressive or antisocial behavior.

\section{Conclusion}

The present research indicates that eating protein, starchy, sugary food items; legumes, fruits and vegetables reduce depression in male and female students, while eating fatty food items and drinking beverages like (tea, coffee ...etc.) increase the depression. Self-esteem is increased by eating protein, starchy, sugary food items and legumes, but is decreased by eating fruits and vegetables and drinking beverages. Eating protein, starchy, sugary food items can lower anxiety. Also, eating legumes, fruits and vegetables reduced anxiety and aggression. Drinking beverages can increase anxiety and aggression. Also, aggression is increased by eating protein food items in male and female students. 


\section{References}

\section{American Heart Association (2010):}

Diet and LifestyIRecommendations. Article reviewed by Danielle Last updated on: Jan 3.

\section{Armando D'Elia (1997):}

Consequences of Meat Protein on Human Behavior. 6th European Vegetarian Congress. Bussolengo, Italy, September 21 - 26, 1997.

Baños RM, Guillén V. (2000):

Psychometric characteristics in normal and social phobic samples for a Spanish version of the Rosenberg SelfEsteem Scale. Psychol Rep. Aug; 87(1):269-74.

Beatrice A. Golomb, Marcella A. Evans, Halbert L. White, Joel E. Dimsdale Golomb BA, Evans MA, White HL, Dimsdale JE (2012):

Trans Fat Consumption and Aggression. PLoS ONE 7(3): e32175.

\section{Benton D (2002):}

Carbohydrate ingestion, blood glucose and mood. Neurosci Biobehav Rev, 26:293-308.

\section{Cathy Wong (2007):}

5 Foods for a Better Mood.About.com Guide .Updated January 07. Health's Disease and Condition content is reviewed by our Medical.

\section{Diana Fishbein\& Susan E. Pease (1995):}

Diet, nutrition, and aggression. Journal of Offender Rehabilitation 21; 3-4. Pages 117-144.Version of record first published: 21 Oct 2010.

Ellie L. Y., David A. N., America B. H., and Bryan K. Y. (2010):

Relational Aggression Among Students Principal Leadership, October, Principals. copyright the National Association of Secondar School.

\section{Gariepy G, Nitka D and Schmitz N (2010):}

The association between obesity and anxiety disorders in the population: a systematic review and metaanalysis. International Journal of Obesity $34,407-419$.

Hamazaki T, Sawazaki S, Itomura M, Asaoka E, Nagao Y, Nishimura N, Yazawa K, Kuwamori T, and Kobayashi M (1996):

The effect of docosahexaenoic acid on aggression in young adults. A placebo-controlled double-blind study. J Clin Invest. February 15; 97(4): 1129-1133.

Janda L. (2001) :

sychologist's book of personality tests : 24 revealing tests to identify and overcome your personal barriers to a better life. New York : John Wiley \& Sons. 
Jerry Shaw (2009):

Protein \& Anxiety MayoClinic.com: Coping with Anxiety -- Can Diet Make a Difference?; May. Article reviewed by Tina Boyle last updated on: May 6, 2011.

\section{Lakhan S, Vieira K (2008):}

Nutritional therapies for mental disorders. Nutr ;7:2.Lew Olson (2010): Can Diet Cause Aggression in Dogs? B-Naturals Newsletter - July.

Liu C, Xie B, Chou CP, Koprowski C, Zhou D, Palmer P, Sun P, Guo Q, Duan L, Sun X, Anderson Johnson C (2007):

Perceived stress, depression and food consumption frequency in the college students of China Seven Cities. Physiol Behav, 92:748-754.

Marci E. Gluck, Allan Geliebter and Tracy Satov (2001):

Night Eating Syndrome Is Associated with Depression, Low Self-Esteem, Reduced Daytime Hunger, and Less Weight Loss in Obese Outpatients. Obesity Research 9, 264-267.

Martin Fisher, Marcie Schneider, Cynthia Pegler, Barbara Napolitano (1991):

Eating attitudes, health-risk behaviors, self-esteem, and anxiety among adolescent females in a suburban high school. Journal of Adolescent Health, Volume 12, Issue 5 , Pages 377-384, July.

\section{Meredith Melnick (2011):}

Eating Fatty Foods May Up Your Risk of Depression. journal PLoS One. January 27, 11. Nancy Schimelpfening (2010): Link Found Between Chocolate and Mood. Archives of Internal Medicine April 26.

National Institute of Mental Health (2009):

NIMH - Depression. Version current September 23. Pouwer F., Nijpels G., Beekman A. T., Dekker J. M., van Dam R. M., Heine R. J. and Snoek F. J. (2005): Fat food for a bad mood. Could we treat and prevent depression in Type 2 diabetes by means of $\omega-3$ polyunsaturated fatty acids? A review of the evidence. Diabet. Med, 22, 1465-1475.

\section{Rafael T Mikolajczyk, Walid El Ansari and Annette E Maxwell (2009):}

Food consumption frequency and perceived stress and depressive symptoms among students in three European countries. Nutrition Journal, 8:31.

Richard S. Strauss (2000):

Childhood Obesity and Self-Esteem. American Academy of Pediatrics.Robinson, J. P., Shaver, P.R. \& Wrightsman, L. S. (Eds.). (1991). Measures of personality and social psychological attitudes. San Diego, CA: Academic Press.

Rob Markus, et al (2009):

The Bovine Protein A-Lactalbumin Increases the Plasma Ratio of Tryptophan to the Other Large Neutral Amino Acids, and in Vulnerable Subjects Raises Brain Serotonin Activity, Reduces Cortisol Concentration, and Improves Mood Under Stress; American Journal of Clinical Nutrition ; December. 
Santucci L.B. , Daud M.M., Almeidal S.S., Oliveira L.M. de (1994):

Effects of early protein malnutrition and environmental stimulation upon the reactivity to diazepam in two animal models of anxiety. Pharmacology Biochemistry and Behavior ; 49( 2), October, Pages 393-398.

Simon Jackson (2011):

Feeling ill or depressed with no apparent cause? Your potato may be at fault. April.

Spielberger, Charles, Gorsuch, Lushene, Vagg and Jacobs (1983):

Review of the State-Trait Anxiety Inventory (STAI). By S. R. Tilton, Ohio University. California. Publisher: Mind Garden Inc. 855 Oak Grove Ave., Suite 215, Menlo Park, CA 94025.

Van Staaden, MJ, Searcy, WA. \& Hanlon, RT. (2011):

'Signaling Aggression' in Aggression Academic Press, Stephen F. Goodwin.

Von Bothmer MI, and Fridlund B (2005):

Gender differences in health habits and in motivation for a healthy lifestyle among Swedish university students. Nurs Health Sci, 7:107-118.

Zellner DA, Loaiza S, Gonzalez Z, Pita J, Morales J, Pecora D, Wolf A (2006):

Food selection changes under stress. Physiol Behav. 
Appendix (A)

Depression Scale

Please circle the appropriate response for each item below.

\begin{tabular}{|c|c|c|c|c|c|}
\hline No. & Items & $\begin{array}{l}\text { None or } \\
\text { a little of } \\
\text { the time }\end{array}$ & $\begin{array}{l}\text { Some } \\
\text { of the } \\
\text { time }\end{array}$ & $\begin{array}{l}\text { Good part } \\
\text { of the } \\
\text { time }\end{array}$ & $\begin{array}{c}\text { Most or all } \\
\text { of the } \\
\text { time }\end{array}$ \\
\hline 1 & I feel down-hearted, blue, and sad. & & & & \\
\hline 2 & Morning is when I feel the best. & & & & \\
\hline 3 & I have crying spells or feel like it. & & & & \\
\hline 4 & I have trouble sleeping through the night. & & & & \\
\hline 5 & I eat as much as I used to. & & & & \\
\hline 6 & $\begin{array}{l}\text { I enjoy looking, talking to, and being with attractive } \\
\text { men/women. }\end{array}$ & & & & \\
\hline 7 & I notice that I am losing weight. & & & & \\
\hline 8 & I have trouble with constipation. & & & & \\
\hline 9 & My heart beats faster than usual. & & & & \\
\hline 10 & I get tired for no reason. & & & & \\
\hline 11 & My mind is as clear as it used to be. & & & & \\
\hline 12 & I find it easy to do the things I used to. & & & & \\
\hline 13 & I am restless and can't keep still. & & & & \\
\hline 14 & I feel hopeful about the future. & & & & \\
\hline 15 & I am more irritable than usual. & & & & \\
\hline 16 & I find it easy to make decisions. & & & & \\
\hline 17 & I feel that I am useful and needed. & & & & \\
\hline 18 & My life is pretty full. & & & & \\
\hline 19 & I feel that others would be better off if I were dead. & & & & \\
\hline 20 & I still enjoy the things I used to do. & & & & \\
\hline
\end{tabular}




\section{Appendix (B)}

\section{Self-Esteem Scale}

Please circle the appropriate response for each question below as it relates to you.

\begin{tabular}{|l|l|l|l|l|l|}
\hline No. & \multicolumn{1}{|c|}{ Items } & $\begin{array}{c}1 \\
\text { Strongly } \\
\text { Agree }\end{array}$ & $\begin{array}{c}2 \\
\text { Agree }\end{array}$ & $\begin{array}{c}3 \\
\text { Disagree }\end{array}$ & $\begin{array}{c}\text { Strongly } \\
\text { Disagree }\end{array}$ \\
\hline 1 & $\begin{array}{l}\text { I feel that I am a person of worth, at least on an equal } \\
\text { basis with others. }\end{array}$ & & & \\
\hline 2 & I feel that I have a number of good qualities. & & & \\
\hline 3 & All in all, I am inclined to feel that I am a failure. & & & & \\
\hline 4 & I am able to do things as well as most other people. & & & & \\
\hline 5 & I feel I do not have much to be proud of. & & & & \\
\hline 6 & I take a positive attitude toward myself. & & & & \\
\hline 7 & On the whole, I am satisfied with my self. & & & & \\
\hline 8 & I wish I could have more respect for myself. & & & & \\
\hline 9 & I certainly feel useless at times. & & & & \\
\hline 10 & At times I think that I am no good at all. & & & \\
\hline
\end{tabular}




\section{Appendix (C)}

Anxiety

A number of statements which people have used to describe them selves are listed below. Read each statement and then circle the appropriate number to the right of the statement to indicate how you generally feel.

\begin{tabular}{|c|c|c|c|c|c|}
\hline No. & Items & $\begin{array}{l}\text { Almost } \\
\text { Never }\end{array}$ & $\begin{array}{l}\text { Some- } \\
\text { times }\end{array}$ & Often & $\begin{array}{l}\text { Almost } \\
\text { Always }\end{array}$ \\
\hline 1 & I feel pleasant. & & & & \\
\hline 2 & I feel nervous and restless. & & & & \\
\hline 3 & I feel satisfied with myself. & & & & \\
\hline 4 & I wish I could be as happy as others seem to be. & & & & \\
\hline 5 & I feel like a failure. & & & & \\
\hline 6 & I feel rested. & & & & \\
\hline 7 & I am "calm, cool, and collected. & & & & \\
\hline 8 & $\begin{array}{l}\text { I feel that difficulties are piling up so that I cannot overcome } \\
\text { them. }\end{array}$ & & & & \\
\hline 9 & I worry too much over something that really doesn't matter. & & & & \\
\hline 10 & I am happy. & 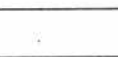 & & & \\
\hline 11 & I have disturbing thoughts. & & & & \\
\hline 12 & I lack self-confidence. & & & & \\
\hline 13 & I feel secure. & & & & \\
\hline 14 & I make decisions easily. & & & & \\
\hline 15 & I feel inadequate. & & & & \\
\hline 16 & I am content. & & & & \\
\hline 17 & $\begin{array}{l}\text { Some unimportant thought runs through my mind and } \\
\text { bothers me. }\end{array}$ & & & & \\
\hline 18 & $\begin{array}{l}\text { I take disappointments so keenly that I can't put them out of } \\
\text { my mind. }\end{array}$ & & & & \\
\hline 19 & I am a steady person. & & & & \\
\hline 20 & $\begin{array}{l}\text { I get in a state of tension or turmoil as I think over my recent } \\
\text { concerns and interests. }\end{array}$ & & & & \\
\hline
\end{tabular}


Appendix (D)

Aggression Scale

Please circle the appropriate response for each item below.

\begin{tabular}{|c|c|c|c|c|}
\hline No. & Items & Often & $\begin{array}{c}\text { Some- } \\
\text { times }\end{array}$ & Rarely \\
\hline 1 & Write on the seats, which sit in the lecture & & & \\
\hline 2 & Interrupt my teacher during the explanation in the lecture & & & \\
\hline 3 & Ideas that came to me and I give my teachers & & & \\
\hline 4 & I refuse to help my teachers in the classroom and terraces & & & \\
\hline 5 & I am working to provoke my teachers and raise their nerve & & & \\
\hline 6 & Issued voices inside the lecture to see me without my teachers & & & \\
\hline 7 & feel a strong desire to break the tools my colleagues & & & \\
\hline 8 & I feel happy when my colleagues Bothered & & & \\
\hline 9 & Bothered my colleagues explain during lectures & & & \\
\hline 10 & I hate lectures, and I want to not to attend & & & \\
\hline 11 & Baptized insult my teachers directing tough questions to them & & & \\
\hline 12 & Baptized saying hurtful words to my colleagues & & & \\
\hline 13 & Rumors tell my colleagues on the & & & \\
\hline 14 & I force my control to my colleagues & & & \\
\hline 15 & My relationships with my colleagues based on mutual respect & & & \\
\hline
\end{tabular}


Nareman S. Eshak and Samuel T. Boshra

\section{Appendix (E)}

Diet History

\begin{tabular}{|c|c|c|c|}
\hline Type of food & Quantiy/day & $\begin{array}{l}\text { Quantity } \\
\text { /week }\end{array}$ & $\begin{array}{l}\text { Quantity } \\
\text { /month }\end{array}$ \\
\hline $\begin{array}{l}\text { 1- Protein foods: } \\
\text { - Meat } \\
\text { - Poultry } \\
\text { - Fish } \\
\text { - Eggs } \\
\text { - Cheese } \\
\text { - Milk }\end{array}$ & & & \\
\hline $\begin{array}{l}\text { 2- Starchy foods: } \\
\text { - Bread } \\
\text { - Rice } \\
\text { - Pasta } \\
\text { - Potatoes } \\
\text { - Grits }\end{array}$ & & & \\
\hline $\begin{array}{l}\text { 3- Sugary foods: } \\
\text { - Sugar } \\
\text { - Honey } \\
\text { - Jam } \\
\text { - Halva }\end{array}$ & & & \\
\hline $\begin{array}{l}\text { 4- Fatty foods: } \\
\text { - Oil } \\
\text { - Margarine } \\
\text { - Butter }\end{array}$ & & & \\
\hline 5-Legumes & & & \\
\hline 6-Fruits/Vegetables & & & \\
\hline 7-Beverages & & & \\
\hline
\end{tabular}


دور التغذية في الصحة النفسية بين الطلاب من جامعة أسيوط

\author{
* ناريمان سعيد إسحق ** صمويل تامر بشرى \\ * مدرس تغذية و علوم أطعمةـ قسم الاقتصاد المنزلي ـكلية التربية النوعيةـ جامعة أسيوط \\ * * أستاذ الصحة النفسية المساعدـ قسم علم النفس - كلية التربية- جامعة أسيوط

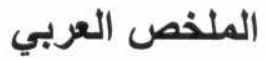

قد نتناول بعض المواد الغذائية تحت ضغوط شخصية خارجية او اكتناب. درسنا العادات الغذائية المرتبطة بالاكتثاب والقلق، وتقدير الذات و العدوان والعلاقة بين الجنسين في عينة من الطلاب من جامعة أسيوط.

ناقشت الدراسة دور التغذية في الصحة النفسية: الاكتناب والقلق واحترام الذات والعدوان في عينة من طلاب من جامعة أسيوط.

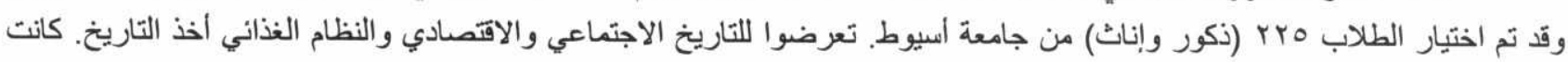

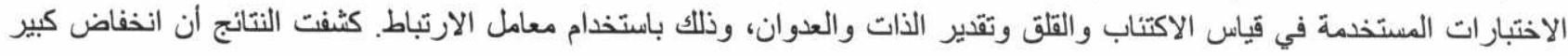

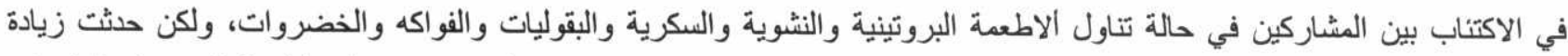

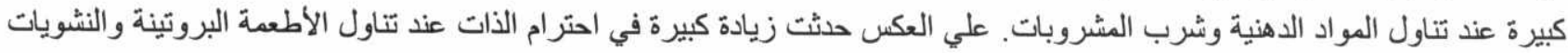

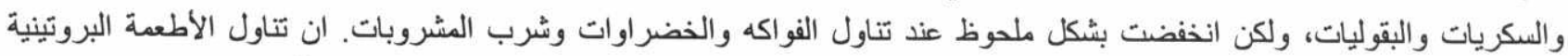

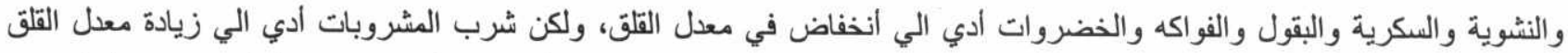

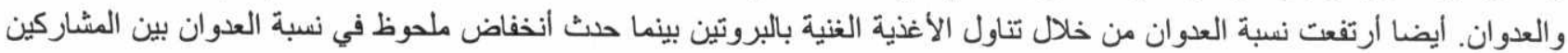
عند تناول البقوليات و الفاكهة والخضروات الغنات 